\title{
Evaluating the Effect of Marketing Activities on Relationship Quality in the Banking Sector: The Case of Private Commercial Banks in Jordan
}

\author{
Basheer. A.M. Al-alak \\ Department of Marketing, AL-Zaytoonah Private University of Jordan \\ Faculty of Economics and Administrative Sciences \\ P.O. Box 130, Amman, 11733, Jordan \\ Tel: 96-264-291-511_E-mail: ALALAK_2003@yahoo.com \\ Ibrahim, A.M. Alnawas \\ Marketing and International Management: Reading University \\ Department of Marketing, AL-Zaytoonah Private University of Jordan \\ Faculty of Economics and Administrative Sciences, Jordan \\ Tel: 96-253-650-978 E-mail: Alnawas_s3s@hotmail.com
}

\begin{abstract}
The aim of the study was to investigate and evaluate the marketing activities and performance of relationship quality in bank setting. To analyze data collected from a random sample of 817 clients drawn from five private commercial banks in Jordan, the linear structural relationship (LISREL) model was used to identify structural characteristics of relationship management between the bank employees and clients. The empirical results of this study were fourfold. First, greater employees' relational and client orientation resulted in higher relationship quality. Second, better financial providers'(employees') attributes resulted in higher relationship quality. Third, higher relationship quality resulted in better relationship continuity. Fourth, committed client relationships resulted in client satisfaction, loyalty, positive word of mouth, and promotion. These in turn contributed to the enhancement of bank image.
\end{abstract}

Keywords: Relationship quality, Banking, Services marketing, Relationship management, Jordan

\section{Introduction}

Since Berry (1983) introduced the concept of relationship marketing, many scholars and researchers (e.g. Gronroos, 1990, 1994; Gordon et al. 2008; Palmatier, et al. 2009) have theorized and empirically tested the underlying principles of relationship marketing theory. Building a profitable and sustainable long term relationship with customers (De Wulf et al. 2001), increasing customers retention, developing and maintaining trust and commitment between sellers and customers (Gaur \& Xu, 2009), achieving more customers satisfaction and high customers loyalty (Gaurav, 2008), and cost reduction due to the better understanding of customers needs (Ndubisi, 2004) are central to the relationship marketing theory. The application of relationship marketing theory has even extended into financial services, due to the deregulation policy (Yavas \& Yasin, 2001), the removal of restrictions between banks, building societies and insurance companies (Speed and Smith , 1992), and the vast expansion in the adoption and use of information technologies (Bergeron et al, 2008).

However, although previous literature has stressed the importance of relationship marketing particularly in financial sector, it seems to be that the perception of how both financial institutions and clients perceive relationship marketing is quite different (The Point Staff, 2005). While clients view relationships as the financial institution is acting for their favor based on confidence and trust, financial institutions view relationships marketing in terms of the number of accounts they have. Such observation requires further investigation on the marketing activities of banking sector as a form of financial institutions, and to evaluate the effect of such activities on relationship quality between financial service providers and their clients. Moreover, while a large body of literature in business to business (B-2-B) and business to consumer(B-2-C) market emphasizes the role and the importance of relationship marketing, no studies have been done on testing the cause-effect model of relationship quality in the banking sector in the Arab world (as far as the current researchers knowledge is 
concerned). Therefore, the primary purpose of this paper is to conduct an investigation in the marketing actions (antecedents) affecting relationship quality between Jordanian banks employees and their clients, and the performances (consequences) influenced by relationship quality. It is expected that the higher the bank's relationship marketing efforts such as client orientation, relational orientation, mutual disclosure, and financial service providers' attributes, the higher the relationship quality between financial service providers and clients. As the relationship quality increases, it is likely to have a significant influence on the clients' behavior demonstrated through increased relationship continuity, and word of mouth.

\section{Literature review}

\subsection{Relationship marketing and financial sector}

Morgan and Hunt (1994) defined relationship marketing as all marketing activities directed toward establishing, developing, and maintaining successful relational exchange. Veloutsou et al. (2002) demonstrated that relationship marketing is based upon an ongoing multi-transactional relationship with customers, as opposed to a series of single transactions as in traditional marketing. Moreover, the time consuming process and the huge amount of resources which are allocated for attracting and acquiring customers, have shifted the emphasis of many firms into building and sustaining long-term customer relationships (Ennew and Binks, 1996). Previous literature showed that in order to achieve profitability up to $85 \%$, firms need to improve their customers retentions by $5 \%$. (Reichheld and Sasser, 1990). Hence, the longer a customer stays in the relationship with a company the more profitable will that be to the company (Al-alak, 2006). Therefore, when firms allocate more of their resources on retaining customers under the relationship marketing strategy, this is likely to make marketing more efficient (Kotler, 2003). In addition, Lovelock (2002) argues that firms need to do a continuous assessment and screening for their entire customers base, since not all existing customer relationships are worth keeping Therefore, relationship marketing aims to establish and maintain a solid base of loyal customers who are profitable for the firm (Peppard, 2000). It is argued that as the number of these relationships grows, the loyal customers themselves will frequently help to attract (through word of mouth) new customers with similar relationship potential (Sheth, 2000).

As related to the above argument, it has been suggested that firms' offering can be customized through a mutual relationship of communication and learning process between firms and their customers (Eisingerich \& Bell, 2006). In the financial sector, where some clients have rejected the use of information technology as an alternative approach for personal contact (Prendergast \& Marr, 1994), the role of clients have become more active in the service production/delivery process (Prahalad and Ramaswamy, 2000). It has also been concluded that the more the client participates in the financial institution service delivery process, the higher the opportunity to use cross selling and up selling with the client effectively (Salazar et al. 2007). Moreover, as financial service offerings are hard to be distinguished among competitors, clients have become more price conscious (Claik and Balta, 2006), therefore, it is argued that relationship marketing could mediate such effect (Jham and Khan, 2008). However, it has been suggested that the financial service sector, particularly banking is not well trusted (Taylor, 2007). On one hand, it is hard for such financial products to be evaluated before receiving and actually trying the service; on the other hand, clients in most cases are unfamiliar with the financial products. As a result of that, sales banking staff may exploit their clients, leading to a rise in client-service provider switching. Such switching process might be associated with some incurred transaction costs, which may influence the image of that financial institution negatively due to the bad word of mouth [Heffernan, 1993]. Furthermore, since most services are delivered from frontline employees, then the quality of interaction which Craig and Ramaseshan, (1994) called 'the moment of the truth' becomes very important. Relationship qualitymoment of truth- refers to customer perceptions and evaluations of individual service employees' communication and behavior, such as respect, courtesy, warmth, empathy, and helpfulness (Al-alak, 2006). This involves inducing feelings and emotional states through customer- employee interactions (or service encounters in the services sector). In the financial sector, whenever clients interact personally with financial service providers- that is 'moment of truth'-, they have the opportunity to evaluate, reevaluate or confirm previously held perceptions of their relationships with the service provider (Menon and O' Connor, 2007).

\subsection{Previous Research}

Crosby et al. (1990) studied the relationship quality in services selling and found that a strong buyer-seller relationship is contingent upon cooperative intentions, mutual disclosure and intensive follow up contact. Bergeron et al. (2001) investigated the role of client knowledge, service quality and expertise. The results of the study showed that the relationship between expertise and satisfaction was insignificant. Satisfied customers were less likely to purchase financial products in the future compared with trusting customers, while trusting 
customers were found to be generating less positive word of mouth in terms of recommending the bank to other people compared with satisfied customers. Eisingerich and Bell (2006) reported that clients' involvement in service delivery process means that clients would shoulder responsibility of both 'blame" and "credits" of the negative/positive service outcome and this in return could lead to a decrease in clients switching. Clients' involvement helped in developing a social relationship with financial service providers which resulted in reduced service failure. Finally, an educated client who is knowledgeable about financial institution offerings helped in improving service quality and increased client loyalty. Bergeron et al. (2008) found that a financial institution with a strong customer orientation had a strong effect on "clients' experience of pleasant surprise". In addition, the familiarity (i.e. knowing his/her birthday) with a client was found to have a strong impact on client pleasant. Continuous innovative practices that are not easily copied by other financial services providers had led to higher client satisfaction. Finally, surprising clients (i.e. sending an invitation to attend a particular event) tend to generate a positive word of mouth.

However, Yavas, (2006) studied the extent of congruency of frontline bank employees' perceptions of service quality to their customers. The author found a contrasting result of how clients perceived and evaluated service quality compared to frontline employees. The justifications for that were the weak assessment of clients' service quality perception and the lack of sales staff training. Dolen et al. (2004) demonstrated that both client encounter and relationship satisfaction are mainly influenced by employee performance. Chaio et al. (2008) concluded that a frontline employee was the main factor that influenced clients' loyalty, regardless of the relationship length with client-service provider. Furthermore, O'Loughlin and Szmigin (2007) found that, although financial service providers recognized the significant impact of internal marketing and staff development in delivering a highly satisfactory banking experience for clients, most of them didn't pair their activities with effective internal marketing or employee training programs, due to the difficulty of managing multi-channel with different clients. The rise in the usage of web-based transactions with clients which fostered the service delivery process, had also led to low personal contact, and this in return resulted in deterioration in customer experience and satisfaction and lesser expectations.

\subsection{Development of measures}

A list of variables that may influence relationship quality and may be affected by relationship quality was developed. These variables were carefully selected in the light of previous empirical studies on the subject matter, with slight adaptation by the researchers of this study in order to express more clearly the uniqueness of the banking sector as service providers. All antecedent items were scored on a 7-point Likert scale ranging from ' 1 = strongly disagree' to ' 7 = strongly agree'.

Table 1 summarizes measure characteristics, sample measurement items, and an assessment of the reliability of the multi-item scales.

\section{(Insert table 1 here)}

Client orientation was measured by two indicators such as understanding clients needs $\left(\mathrm{X}_{1}\right)$ and conflict resolution $\left(\mathrm{X}_{2}\right)$. These two indicators consist of multi-items of two and three respectively. Understanding client needs is measured by (1) a bank employee is knowledgeable about clients' needs and (2) a bank employee tries to understand the change of clients needs. Conflict resolution is measured by (1) a bank employee deals with your inquiry and complaint courteously; (2) a bank employee deals with your inquiry and complaint expeditiously; and (3) a bank employee resolves your inquiry or complaint even though these are not in his or her direct responsibility.

Relational orientation was measured by two indicators such as cooperative intention $\left(\mathrm{X}_{3}\right)$ and contact intention $\left(\mathrm{X}_{4}\right)$. The two indicators consist of multi-items of two and four, respectively. Cooperative intention was measured by (1) a bank employee treats you equally and (2) a bank employee helps you make a decision. Contact intention was measured by (1) a bank employee devotes time for you; (2) a bank employee is in constant contact with you; (3) a bank employee provides information about new services; and (4) a bank employee contacts you when necessary.

As an exogenous construct influencing relationship quality, mutual disclosure (X5) is measured by four items including (1) I ask a bank employee extensive questions; (2) a bank employee helps you dealing with a new techservice; (3) a bank employee solves your problem in error transactions; and (4) I have expressed to a bank employee dissatisfaction with service.

Bank employees' attributes consist of three variables namely expertise $\left(\mathrm{X}_{6}\right)$, experience $\left(\mathrm{X}_{7}\right)$, and appearance $\left(\mathrm{X}_{8}\right)$. Each variable consists of four, two, and three items, respectively. Expertise consists of (1) a bank employee 
is professional in providing highly satisfactory service; (2) a bank employee demonstrates adequate knowledge and skills about all services provided by a bank; (3) a bank employee shows interest in self-development to provide better service; and (4) a bank employee is competent in providing service. Experience consists of (1) a bank employee seems to have a lot of experience and (2) a bank employee seems to have excellent career record. Appearance consists of (1) a bank employee's appearance is professional; (2) a bank employee is well dressed; and (3) a bank employee has a nice manner.

The focal variable in this study was the quality of the bank employee- client relationship as perceived by the client. Relationship quality from the clients' perspective is achieved through the employee's ability to reduce perceived uncertainty. High relationship quality means that the client is able to rely on the service providers' future performance since the level of past performance was satisfactory. Relationship quality was a construct consisting of two indicators, trust and satisfaction. Measurement scales for trust and satisfaction were based on the Crosby, Evans, and Cowles study (1990). Five items including (1) keeping promises, (2) sincere, (3) reliable, (4) honest, and (5) puts clients interests first, were used to measure trust. Four items were used to measure satisfaction, namely (1) favorable, (2) pleased, (3) satisfied with bank employee, and (4) satisfied with bank's overall services.

In order to measure consequences of relationship quality, relationship continuity, and word-of-mouth were used. Three items on a Likert scale were used to measure relationship continuity: (1) I believe a bank employee will provide better service in the future; (2) I will not switch to another bank; and (3) I will always be proud of this bank. Two items were used to measure word of mouth namely (1) I want to recommend this bank to others and (2) I want to tell other persons about good things of this bank.

\subsection{Model and hypotheses}

Fig. 1 summarizes the relationship quality model that is tested in this study.

\section{(Insert Fig.1 here)}

\subsection{Antecedents (marketing actions)}

Al-alak (2004) defined variables affecting relationship quality as service provider attributes (e.g. expertise and know-how) and relational selling behavior (e.g. contact intensity, mutual disclosure, and cooperative intention). Crosby et al. (1990) defined exogenous variables affecting relationship quality as similarity, service domain expertise, and relational selling behavior. Kim et al. (2001) developed three relationship management activities (exogenous variables) affecting relationship quality: guest confidence, guest contact, and effective communication.

A list of variables that may influence relationship quality was developed in this study. These four exogenous constructs were client orientation, relational orientation, mutual disclosure, and service providers' attributes.

Client-oriented service providers provide service that goes beyond customer expectations (Chiao et al. 2008) and continue to put clients' needs and interests ahead of any other interest (Al-alak- and Al-taie, 2002). The more client-contact service employees (bank employees) have communicated benefits, the stronger the clients' perception that bank employees put clients' needs first. When employees of client-oriented bank provide superior and highly satisfactory services, the service image of the bank will improve and client satisfaction will increase. Client orientation appears to have a direct relationship with relationship quality.

Relational orientation refers to "customer's psychological attachment, loyalty, concern for future welfare, identification, and pride in being associated with the organization" (Garbarino and Johnson 1999, p.73). Relational exchange characteristics of the buyer and seller were hypothesized to influence relationship quality (Crosby et al., 1990). It is evident that, customers' intentions to remain loyal to a firm become stronger, if the customers treasured highly the relationship with the firm (Walter, 2000). A relational-oriented and zero error service offered to customers was found to be critical for the service provider to achieve a competitive advantage, increase customer loyalty, enhance corporate image, and increase business performance (Choi and Chu, 2001). In the banking sector, we would expect the same. A bank providing excellent services, or when services exceed clients' expectations, especially when such services cannot possibly be matched in terms of perceived quality, could achieve a competitive advantage, enhance its image, and increase client loyalty. This positive state would make the bank in question more popular, as a quality service provider, in the eyes of not only the clients but also the community at large.

Mutual disclosure is a two-way interaction- i.e. between bank employees and clients. In traditional banking, as opposed to e-banking, this kind of interaction is important in establishing and maintaining interpersonal 
relationships (Paulin et al. 1998). Mutual disclosure was also shown to have a positive impact on relationship quality in a traditional banking setting (Prendergast \& Marr, 1994).

Whenever a client interacts with a bank by phone, e-mail, in person, or via technology, a service encounter occurs. During these encounters or moments of truth, clients receive a snapshot of the bank quality and each encounter contributes to the clients' overall satisfaction. Among several service providers' attributes physical appearance is an important determinant of client satisfaction. Several banks have policies regarding the physical appearance of their employees, especially managers. The service providers' attributes and their performance are so important to build good relationship quality in the service encounter.

Therefore, we propose the following hypothesis and sub-hypotheses.

H1. There is a positive relationship between antecedents (clients- orientation, relational orientation, mutual disclosure, and service providers' attributes) and relationship quality.

\section{H1-1. There is a positive relationship between client orientation and relationship quality.}

H1-2. There is a positive relationship between relational orientation and relationship quality.

H1-3. There is a positive relationship between mutual disclosure and relationship quality.

H1-4. There is a positive relationship between the service providers' attributes and relationship quality.

2.6 Consequences (Performances)

Empirical findings of Al-alak and Al-taie (2002) study for quality services provided by hotels in Jordan to foreign guests showed that guest satisfaction had a positive relationship with repurchase intention (i.e. dealing with the hotel on a regular basis) and word of mouth. Satisfied customers show stronger repeat purchase intention and spread word-of-mouth referral. Relationship quality is proposed to have a positive relationship with the following two consequences:

\subsubsection{Word of mouth}

Bendapudi and Berry (1997) suggested that relationship advocacy resulted from dedication-based relationship: the relationship that customers wanted it to continue rather than feeling like he or she has no other choice. Alalak (2004) showed that satisfied customers in his study appeared to engage in extensive word-of-mouth advertising, acting as true promotion agents for the service provider. Previous literature that discussed the involvement of emotional and task focused shopping experience provide findings that propose a direct relationship between these environments and patronage behavior. Other findings indicate "that one's emotional shopping experience and task focused shopping successes are involved in complex views of oneself and word mouth of communication" (Paridon, 2008, P.84). In the banking sector, we expect word of mouth to be a powerful form of communication.

\subsubsection{Relationship continuity}

The value of a relationship in the banking sector is assumed to be rooted in the continuity of the relationship between the bank and client. Relationship continuity is the parties' willingness to prolong the cooperation or agreement to cooperate for a specific period of time. One would expect satisfied clients to remain dealing with the bank without having to think of switching to other competing financial service providers.

Therefore, we offer the following hypotheses and sub-hypotheses:

H2. There is a positive relationship between relationship quality and consequences (relationship continuity and word of mouth).

H2.1. There is a positive relationship between relationship quality and relationship continuity.

H2.2. There is a positive relationship between relationship quality and word of mouth.

H2.3. There is a positive relationship between relationship continuity and word of mouth.

\section{Methodology}

\subsection{Data source and scale}

The required primary data was collected through a self administrated questionnaire which was originally developed and employed for the purpose of the study. A pilot study was first conducted to improve questionnaire structure and content. To achieve this purpose, thirty questionnaires were sent to academicians who work in finance and marketing departments in different Jordanian universities, and another twenty were sent to financial advisors and experts who work in the financial sector. Several statements were revised based on the input from the academicians and experts, and the comments were considered in the final version. Of the original 47 statements, 38 were then selected and used for the research instrument. A random sample of five Jordanian 
banks-clients namely; Arab Bank, Housing Bank, Arab Jordan Investment Bank, Jordan Islamic Bank and Jordan Bank were used. Out of the five banks, only Arab bank is an international bank and the rest of them are private commercial banks. The banks which were chosen are located in three cities namely; Amman, Irbid and Al-zarqa. The sample contained 1000 respondents. Out of the 1000 distributed questionnaires a total of 866 or a response rate of $87 \%$ was returned. Schneider \& Johnson (1995) pointed out that the presence of a university logo on a questionnaire usually gives research more credibility which in return helps to increase response rate and Faria and Dickenson (1996) state that assurances of confidentiality could also result in increasing response rates. Therefore, in the head of the questionnaire there were the university name and logo and a sentence which assured respondents that their answers would be confidential and would be only used for the study purpose. The process of distributing the questionnaire was drop-off approach (Aaker et al. 2004). Based on the logic of this method, the researchers hand delivered the questionnaire randomly in different day's time to the clients in the above mentioned banks after explaining to them the purpose of the study, the required procedure to fill out the questionnaire and answering any question with regard to any of the questionnaire's statements. Some respondents refused to fill the questionnaire due to the time factor, while respondents who showed interest to participate were offered non monetary incentives such as pens and pencil. Dunning et al. (1974) state that offering non monetary incentives could result in increasing response rate. However, after removing the invalid questionnaires, 817 questionnaires were used in our empirical research. The 49 questionnaires were considered invalid because respondents skipped many items. The period of distributing the questionnaire lasted from $1^{\text {st }}$ of February 2009 until the $10^{\text {th }}$ of September 2009. The length of distributing the questionnaire was quite long because the above mentioned banks are located in different geographic areas, which was an obstacle to collect the required data within a short time. In addition, the researchers were distributing on average 20 questionnaires every time they went to a bank, to make it easier to follow up respondents. Moreover, the included banks in the sample were visited four to five times a month.

Questions asked respondents to rate their degree of agreement using a 7-point Likert scale. With the exceptions of mutual disclosure, relationship continuity, and word of mouth, all constructs had multiple indexes. Some of the indicators such as $\mathrm{X}_{1}$ through $\mathrm{Y}_{2}$ are themselves multi-item scale, while other indicators such as $\mathrm{Y}_{3}$ through $\mathrm{Y}_{7}$ were single items (see Fig. 1 and Table 1). Several statistical techniques including an exploratory, confirmatory factor analysis, correlation analysis, reliability test, and linear structural relationship (LISREL) were used in this study. In order to test the model and hypotheses that were previously stated, structural equation modeling was used.

\section{Results}

The data obtained from the survey were analyzed for frequency analysis. Among respondents, male was $64 \%$ (523) and female was 36\% (294). 41\% of respondents were between the ages of 19 and 34. Respondents at the age of 35 and above constituted $59 \%$ of total respondents. Respondents' income below $\$ 140$ (per month) was $22 \% ; 63 \%$ of respondents' income was between $\$ 140$ and $\$ 420$, and the rest of respondents' income (15\%) was above $\$ 420$. Respondents who have had a relationship with their banks for less than 3 years were 345 respondents (\%42), 196 respondents $(\% 24)$ have had a relationship for 3 to 5 years, and 276 respondents (\%34) have had a relationship for more than 5 years.

\subsection{Confirmative factor analysis and correlation analysis}

Initially, the set of items corresponding to each theoretical construct was subjected to examination of item-tototal correlation and exploratory factor analysis (Churchill, 1979) (see Table 2).

\section{(Insert table 2 here)}

After this initial analysis, the entire set of items was subjected to confirmatory factor analysis to verify unidimensionality. Specifically, a measurement model was estimated in which every item was restricted to load on its a priori specified factor, and the factors themselves were allowed to correlate (Gerbing and Anderson, 1988). A confirmatory factor analysis was conducted for all seven constructs and their indicators. An adequate degree of model fit was obtained $\left(\chi^{2}=266.21, \mathrm{P}=0.08, \mathrm{GFI}=0.91, \mathrm{AGFI}=0.88, \mathrm{RMSR}=0.032\right)$. Overall the global measurement model provided satisfactory evidence of unidimensionality for the measure.

Table 3 represents the means, standard deviations, and intercorrelations for all constructs. The correlation among each construct was significant at the 0.01 level.

(Insert table 3 here) 


\subsection{Reliability test}

The final step in the measurement validation involved computing coefficient alpha for each set of measures to test reliability. Cronbach's alpha is most often used to test the reliability of a multi-item scale. The cut-off point is generally 0.6 (Hair et al., 1992). Since all the $\propto$ values were in between 0.75 and 0.85 and all above 0.74 the construct in our model resulted in being very reliable (see Table 1). In sum, the evidence suggested that our scale had adequate measurement properties.

\subsection{Overall model fit}

The relationships among the variables were assessed simultaneously via covariance analysis. Maximum likelihood (ML) estimation was used to estimate model parameters. The ML estimation method is suited to theory testing and development. For model fit assessment, several diagnostics were used to judge the simultaneous fit of the measurement and structural models to the data collected for the study. The goodness-offit index (GFI) for the overall model was 0.91 and adjusted goodness-of-fit index (AGFI) was 0.88 . The model showed significant chi square value $\left(\chi^{\mathrm{s}}=198.61, \mathrm{P}=0.07\right)$. Other diagnostics such as root mean square residual (RMSR) was 0.043. This model had the normed fit index (NFI) value of 0.99 (See Table 4). This means that $99 \%$ of the observed-measure covariance is explained by the composition model. The structural model fit is within an acceptable level.

\section{(Insert table 4 here)}

With the exception of the path from mutual disclosure to relationship quality, all hypothesized paths were supported at the 0.05 level of significance. Contrary to the initial hypothesis, mutual disclosure was not found to be significantly related to relationship quality $\left(\gamma_{13}=-0.08, \mathrm{t}=-1.00\right)$. Thus, the results indicate that H1-3 was not supported. Client orientation, relational orientation, and service providers' attributes were all positively related to relationship quality $\left(\gamma_{11}=0.28, \mathrm{t}=4.83, \gamma_{12}=1.46, \mathrm{t}=5.69, \gamma_{14}=0.21 \mathrm{t}=1.98\right)$ at the 0.05 level of significance. Thus, the results supported H1-1, H1-2, and H1-4 and client orientation, relational orientation, and service providers' attributes had a positive influence on relationship quality.

Relationship quality was positively related to relationship continuity $\left(\beta_{31}=0.17, \mathrm{t}=4.28\right)$, and word of mouth $\left(\beta_{41}=0.15, \mathrm{t}=4.15\right)$ at the 0.05 level of significance. Thus, these results supported H2-1 and H2-2. Relationship continuity was found to be significantly related to word of mouth $\left(\beta_{34}=0.81, t=6.56\right)$ at the 0.01 level. Thus the results supported $\mathrm{H} 3$.

\section{Conclusion}

The field/analytical study has examined the marketing actions and performances of relationship quality in a bank setting, and demonstrated that relationship marketing activities conducted by financial service providers do create and add value for clients, leading to not only client satisfaction and trust but also to long term relationship, and positive word of mouth. It has also been demonstrated that well-planned and executed client relationship management on the part of the bank in question represents a great opportunity to increase client value and provides a way to systematically attract, acquire and retain clients, as well as to enhance the image of the bank as quality financial service provider. The findings of this study showed how each of the proposed marketing actions (antecedents) provided an opportunity to bank managers who should develop and implement relationship marketing strategy with the general goal of increasing marketing efficiency and effectiveness. Four hypothesized sets of marketing actions (relational orientation, client orientation, financial service providers' attributes, and mutual disclosure) were tested. Only mutual disclosure was found to have no significant relationship with service quality. The other three hypothesized sets of marketing actions had a positive effect on relationship quality at the 0.05 level of significance. The findings showed that relationship quality was strongly and positively influenced by relational orientation, followed by client orientation and financial service providers' attributes. This study suggested that bank managers emphasizing relational orientation, client orientation, and financial service providers (assistants, supervisors and all other bank's employees who come in direct contact with clients) should be equipped with expertise, experience and professional appearance to enhance client trust and satisfaction. It will eventually lead to improved performance related to relationship continuity and word of mouth. It can be concluded from the results of this study that high quality financial institutions can play an important role in reducing the perceived risk, create and add value for clients, provide zero error services, increase client satisfaction and pursuit best practices and excellence in the field of financial services.

In order to enhance the employee's relational orientation, bank managers (e.g. assistants, supervisors and tellers) must maintain well-planned and organized interactions with clients. Some of the useful interactions and activities include (1) consistent communication with clients via phone calls, electronic mail, newsletters, and 
telemarketing; (2) solving client problems, helping them in dealing with new tech-services, telling them about new services that might save their time, and increasing client involvements which helps in delivering superior services and, (3) provide constant financial reports and information about bank achievements which may result in increasing the credibility of the institution in the eyes of clients. It is evident that, communication plays a vital role in maintaining a long-term relationship between the bank and its clients and the community at large. Clientbank communication can be encouraged by training and developing not only frontline skills, but the bank employees as a whole. Recommendations from satisfied customers were found in previous literature to constitute a corner stone and vital factor in purchasing financial products. Therefore, when bank employees are equipped with the required skills to serve and understand their clients needs, positive words of mouth may flourish, resulting in recommending that bank to family members, friends and relatives. Feedback loops can also help in developing two way communications where financial service providers can learn from customers.

In order to improve client orientation, the bank should translate the detailed information about their clients into actionable practices. One-to-one marketing seems to be reasonable in helping banks to generate the required information about their clients' behavior. This information then could be aligned with the bank strategy to deliver high quality service, resulting in high client satisfaction. Serving a client as an individual and not merely as a number initiates the following activities which should be implemented to understand clients' characteristics and preferences better: (1) be knowledgeable about the clients' unique preferences (especially worthy clients and VIPs) and (2) try to understand and predict changes in clients needs. Integrating all bank activities -front and back offices- into one system can help in dealing with clients smoothly, since all the required information about the client is easily accessible. Activities of bank employees for problem resolution include the following: (1) show care and courtesy when dealing with client inquiry and complaints, (2) devote more time to listen and trying to truly understand client point of view and (3) resolve clients' inquiry and complaints even though these may not be in employees' direct responsibilities.

It is important for all bank employees to have the following expertise in the client encounter: (1) professional and skillful in dealing with clients; (2) adequate knowledge about the bank's mission and objectives; (3) adequate knowledge about different financial service products; (4) show interest in self-development to provide better financial services; and (5) be competent in providing financial services. It is also important for bank employees to have appropriate and sufficient experience to identify client needs. Employees should be able to: (1) advice clients; (2) identify their needs (3) provide solutions for their problems (3). The findings of this study indicate that it is important for bank employees to be well dressed and have professional appearance with a nice manner to make clients satisfied. This, however, may affect 'the moment of truth', where clients assess/reassess previously held perceptions. Once the bank has acquired a satisfied client, it possibly leads to more and more clients wanting to do transaction with the bank, and can achieve positive effects of relationship continuity and word of mouth. Therefore, it is a most important task for the bank to make clients satisfied and to create a higher level of clients' trust in the service providers' behavior.

Finally, relationship quality in the bank setting should be considered by those in charge of the bank (e.g. general managers, assistants, tellers) as the ability to meet the stated and implied requirements of the clients and employees alike rather than elegance. Ideal relationship quality in our case may enable the bank to develop ties of trust and long term commitment with their clients. Such commitment may increase the length of client-service relationship, allowing the bank to increase its credibility and enhance its brand name and position itself as a market leader in delivering zero error financial services.

\subsection{Limitations and directions for future research}

This study was subject to several limitations that affected the interpretation of the results. Future research might explore other aspects of client-service provider relationship to measure antecedents of relationship quality. The effect of the demographic characteristics of clients (such as income and age) could be further studied and investigated in the Arab World. There is also a need for measuring the effect of such variables on the length of relationship between clients and financial service providers. A further interesting field of study could be through conducting a comparative study between Jordanian and non Jordanian banks operating in the same sector. This study was confined to five Jordanian banks out of fourteen. A future study should extend the research subject to all banks and other financial institutions such as insurance companies, building societies and financial markets.

\section{References}

Aaker, D., Kumar, V., and, Day, G. S. (2004). Marketing Research, 8th edition, John Wiley \& sons, Inc., New York, P. 259. 
Al-alak, A. M. (2006). The Impact of Marketing Actions on Relationship Quality in the Higher Education Sector in Jordan. Journal of Marketing for Higher Education, 2006, Vol. 16 Issue 2, pp.1-23.

AL-alak, B.A \& Al-taie, H.A. (2002). Perceived Quality of Services Provided by Hotels in Jordan Among Foreign Guests (A Field Study), Dirasat. University of Jordan. Vol. 29 Issue (2), pp. 497-516.

Al-alak, B.A. (2004). Methods of Enhancing Customer Loyalty to the Providers of Online and Offline Supporting Services in the Mobile Telecommunication Sector (A Field/ Analytical Study), Dirasat, University of Jordan. Vol. 31 Issue 2, pp. 278-297.

Bendapudi, N., and Berry, L. L. (1997). Customers' Motivations for Maintaining Relationships with Service Providers. Journal of Retailing. Vol. 73 Issue 1, pp. 15-37.

Bergeron, J. Roy, J., and Fallu, J. (2008). Pleasantly Surprising Clients: A Tactic in Relationship Marketing for Building Competitive Advantage in the Financial Services Sector. Canadian Journal of Administrative Sciences. Vol. 25 Issue 3, p171-184.

Bergeron, J., Richard, L., and Perrien, J. (2003). Relationship marketing: The role of client knowledge, service quality and expertise. Actes du9 Colloque International du Marketing Relationnel. Montreal Canada, p79-91.

Berry , L. L. (1983). Relationship marketing, in Berry, L.L., Shostack, G. L. and Opah, G. (eds) ' Emerging Perspectives on Service Marketing, American Marketing Association, Chicago, IL .

Chiao,Y-C., Chiu, Y-K and Guan, J-L. (2008). Does the length of a customer-provider relationship really matter? Service Industries Journal, Jul2008, Vol. 28 Issue 5, p649-667.

Choi. T.Y., and Chu, R. (2001). Determinants of hotel guests' satisfaction and repeat patronage in the Hong Kong hotel industry. International Journal of Hospitality Management, Vol. 20, Issue (3), pp 67-82.

Churchill., G.A. (1979). A paradigm for developing better measures of marketing constructs. Journal of Marketing Research, 16 (1). 64-73.

Claik, N., and Balta, N. F. (2006). Consumer satisfaction and loyalty derived from the perceived quality of individual banking services: A field study in Eskişehir from Turkey. Journal of Financial Services Marketing, Vol. 10 Issue 4, p135-149.

Copulsky. J.R., and Wolf, M.J. (1990). Relationship marketing positioning for the future. The Journal of Business Strategy, Vol. 11 Issue (4), pp. 16-20.

Craig , C. J., and Ramaseshan, B. (1994). The role of customer-contact personnel in the marketing of a retail bank's services. International Journal of Retail \& Distribution Managemen, Vol. 22 Issue 5, pp. 29 - 34.

Crosby, L.A., Evans, K.R., \& Cowles, D. (1990). Relationship quality in services selling: an interpersonal influence perspective. Journal of Marketing, Vol. 54 Issue 3, pp. 68-81.

De Wulf, K., Gaby O and Dawn Iacobucci. (2001). Investments in Consumer Relationships: A Cross-Country and Cross-Industry Exploration. Journal of Marketing, Vol. 65 Issue 3, pp. 33-50.

Dunning, Bruce and Don Cahalan. (1973-74). By Mail vs. Field Self-Administered Questionnaires: An Armed Forces Survey. Public Opinion Quarterly. Vol. 37 (Winter), 618-24.

Eisingerich, A. B., and Bell, S. J. (2006). Relationship marketing in the financial services industry: The importance of customer education, participation and problem management for customer loyalty. Journal of Financial Services Marketing, Vol. 10 Issue 4, p86-97.

Ennew, C.T., and Binks, M.R. (1996). Good and Bad Customers: The Benefits of Participating in the Banking Relationship. International Journal of Bank Marketing, Vol. 14 Issue (2), pp. 5-13.

Faria, A.J., \& Dickinson, J.R. (1996). The Effect of Reassured Anonymity and Sponsor on Mail Survey Response Rate and Speed with a Business Population. Journal of Businessand Industrial Marketing, 11(1), 66-76.

Garbarino, E., and M. S. Johnson. (1999). The different roles of satisfaction, trust, and commitment in customer relationships. Journal of Marketing, Vol.63 (April), pp. 70-87.

Gaur, S., and Xu, Y. (2009). Consumer Comfort and Its Role in Relationship Marketing Outcomes: An Empirical Investigation. Advances in Consumer Research - Asia-Pacific Conference Proceedings. Vol. 8, p296-298. 
Gaurav, K. (2008). Impact of Relationship Marketing Strategy on Customer Loyalty. ICFAI Journal of Management Research, Vol. 7 Issue 11, pp7-21.

Gerbing. D.W., and Anderson. J.C. (1988). An updated paradigm for scale development incorporating unidimensionalily and its assessment. Journal of Marketing Research, 25 (2). 186-192.

Gordon, T. L., Pires, G. D., and Stanton, J. (2008). The relationship marketing orientation of Hong Kong financial services industry managers and its links to business performance. Journal of Financial Services Marketing, Vol. 13 Issue 3, p193-203.

Gronroos, C. (1990). Servjce Management and Marketing: Managing the Moments of Truth in Service Competition. Lexington, MA Lexington Books.

Gronroos, C. (1994). Quo Vadis, Marketing? Toward a Relationship Marketing Paradigm. Journal of Marketing Management, Vol. 10, Issue. 5, pp.347-360.

Gronroos, C. (1997). Value Driven Relationship Marketing: from products to resources and competences. Journal of Marketing Management, Vol.13 Issue 5, pp. 407-19.

Hair. J., Anderson, R., Tatham. R., and Black, W. (1992). Multivariate Data Analysis, 2nd Edition. Macmillan. New York.

Heffernan, S. A. (1993). Competition in British Retail Banking. Journal of Financial Services Research, Vol. 7 Issue 4, p309-332.

Jham, V., and Khan, K. M. (2008). Determinants of Performance in Retail Banking: Perspectives of Customer Satisfaction and Relationship Marketing. Singapore Management Review, Vol. 30 Issue 2, p35-45.

Kim. W.G., Han. J.S., and Lee, E. (2001). Effects of relationship marketing on repeat purchase and word of mouth. Journal of Hospitality \& Tourism Research, Vol. 25 Issue (3), pp. 272-288.

Kotler, P. (2003). Marketing Management: Analysis, Planning, Implementation and Control. Prentice-Hall, 316-321.

Loughlin, O., and Szmigin, D. (2007). The Challenge of Sustaining the Relationship Approach: Financial Supplier Perspectives. Australasian Marketing Journal, Vol.15 Issue 3, pp. 35-48.

Lovelock, C. (2002). Services Marketing. Prentice-Hall, 112-118.

Menon, K., and O'Connor, A. (2007). Building customers' affective commitment towards retail banks: The role of CRM in each 'moment of truth'. Journal of Financial Services Marketing, Vol. 12 Issue 2, p157-168.

Morgan. R.M., and Hunt, S.D. (1994). The commitment-trust theory of relationship marketing. Journal of Marketing, Vol. 58 Issue 3, pp. 20-38.

Ndubisi, N. O. (2004). Understanding the Salience of Cultural Dimensions on Relationship Marketing, its Underpinnings and Aftermaths. Cross Cultural Management, Vol. 11, No. 3, pp. 70-89.

Palmatier, R. W., Jarvis, C. B., Bechkoff, J. R., and Kardes, F. R. (2009). The Role of Customer Gratitude in Relationship Marketing. Journal of Marketing, Sep2009, Vol. 73 Issue 5, p1-18.

Paridon, T. (2008). CONSUMER SELF-CONFIDENCE AND PATRONAGE INTENSITY HEURISTICS IN SHOPPING FOCUSED WORD OF MOUTH COMMUNICATION. Marketing Management Journal, Spring2008, Vol. 18 Issue 1, p84-99.

Paulin , M., Perrien, J., Ferguson , R. J., Salazar, A. M. A., and Seruya, L. M. (1998). Relational norms and client retention: External effectiveness of commercial banking in Canada and Mexico. International Journal of Bank Marketing, Vol. 16 Issue 1, pp. $24-31$.

Peppard, J. (2000). Customer Relationship Management (CRM) in Financial Services. European Management Journal, Vol. 18 Issue 3, pp. 312-327.

Point for Credit Union Research \& Advice. (2005). BAI Report: Most Consumers Aren't Looking for Financial Relationships.

Prahalad, C. K., and Ramaswamy, V. (2000). Co-opting Customer Competence. Harvard Business Review, Vol. 78 Issue 1, pp.79-87.

Prendergast, G. P., and Marr, N. E. (1994). The Future of Self-Service Technologies in Retail Banking. Service Industries Journal, Vol. 14 Issue 1, pp94-114. 
Pressey, A., and Tzokas, N. (2006). Editorial: Relationship Marketing: Theory, Applications and Future Research Directions. Journal of Marketing Management, Feb2006, Vol. 22 Issue 1/2, p1-4.

Reichheld, F., and Sasser, W.E. (1990). Zero defections: quality comes to services. Harvard Business Review, Vol. 68 Issue (5), pp. 105-111.

Salazar, M. T., Harrison, T., and Ansell, J. (2007). An approach for the identification of cross-sell and up-sell opportunities using a financial services customer database. Journal of Financial Services Marketing, Vol. 12 Issue 2, p115-131.

Schneider, K.C., \& Johnson, J.C. (1995). Stimulating Response to Market Surveys of Business Professionals. Industrial Marketing Management, 24(4), 265-276.

Sheth, J.N. (2000). Handbook of Relationship Marketing. Thousand Oaks, Cai Sage Publications, 26-31.

Speed, R., and Smith, G. (1992). Retail fi nancial services segmentation. Service Industries Journal, Vol. 12 Issue. 3, pp. $368-383$.

Taylor, D. (2007). Caveat emptor in the financial services market. Consumer Policy Review, Vol. 17 Issue 6, p265-268.

Van Dolen, W., De Ruyter, K., \& Lemmink, J. (2004). An empirical assessment of the influence of customer emotions and contact employee performance on encounter and relationship satisfaction. Journal of Business Research, Vol. 57, pp. 437-444.

Veloutsou C., Saren, M., and Tzokas, N. (2002), Relationship marketing: what if....? European Journal of Marketing, Vol. 36 issue 4, pp. 433-449.

Walter, A. (2000). The impact of satisfaction, trust, and relationühip value on commit me lit: Theorelical considerations and empirical results. Proceedings of the 16lh IMF Conference. University of Bath, Bath, UK.

Yavas, U. (2006). How similar are frontline bank employees' perceptions of service quality to their customers? A study of female customers and employees in Turkey. Journal of Financial Services Marketing, Vol. 12 Issue 1, pp. 30-38.

Yavas, U., and Yasin, M. M. (2001). Enhancing organizational performance in banks: a systematic approach. Journal of Services Marketing, Vol. 15 Issue 6/7.

Table 1. Summary of Measure

\begin{tabular}{|l|l|}
\hline Client orientation & \\
\hline$\alpha=0.85$ & Index of understanding client needs (strongly agree 7... strongly disagree 1) \\
\hline & A bank employee is knowledgeable about clients' needs \\
\hline$\alpha=0.79$ & A bank employee tries to understand the change of clients' needs \\
\hline & Index of conflict resolution (strongly agree 7... strongly disagree 1) \\
\hline & A bank employee deals with your inquiry and complaint courteously \\
\hline & A bank employee deals with your inquiry and complaint expeditiously \\
\hline Relational orientation & $\begin{array}{l}\text { A bank employee resolves your inquiry or complaint even though these are not } \\
\text { in his or her direct responsibility }\end{array}$ \\
\hline$\alpha=0.75$ & \\
\hline & Index of cooperative intention (strongly agree 7... strongly disagree 1) \\
\hline & A bank employee treats you equally \\
\hline$\alpha=0.77$ & A bank employee helps you make a decision \\
\hline & Index of contact intention (strongly agree 7... strongly disagree 1) \\
\hline & A bank employee devotes time for you \\
\hline & A bank employee is in constant contact with you (phone, fax, e-mail, letter, etc). \\
\hline & A bank employee provides information about new services \\
\hline Mutual disclosure & A bank employee contacts you when necessary \\
\hline$\alpha=0.84$ & \\
\hline & (strongly agree 7... strongly disagree 1) \\
\hline & I ask a bank employee extensive questions \\
\hline & A bank employee helps you dealing with a new tech-service \\
\hline & A bank employee solves your problem in error transaction \\
\hline & I have expressed to a bank employee dissatisfaction with service \\
\hline
\end{tabular}




\begin{tabular}{|c|c|}
\hline $\begin{array}{l}\text { Bank employees' attributes } \\
\text { (service providers' attributes) }\end{array}$ & \\
\hline \multirow[t]{5}{*}{$\alpha=0.76$} & Index of expertise (strongly agree $7 \ldots$ strongly disagree 1 ) \\
\hline & A bank employee is professional in providing highly satisfactory service \\
\hline & $\begin{array}{l}\text { A bank employee demonstrates adequate knowledge and skills } \\
\text { about all services provided by a bank }\end{array}$ \\
\hline & A bank employee shows interest in self- development to provide better service \\
\hline & A bank employee is competent in providing service \\
\hline \multirow[t]{3}{*}{$\alpha=0.84$} & Index of experience (strongly agree $7 \ldots$ strongly disagree 1 ) \\
\hline & A bank employee seems to have a lot of experience \\
\hline & A bank employee seems to have excellent career record \\
\hline \multirow[t]{4}{*}{$\alpha=0.79$} & Index of appearance (strongly agree $7 \ldots$ strongly disagree 1 ) \\
\hline & A bank employee's appearance is professional \\
\hline & A bank employee is well dressed \\
\hline & A bank employee has a nice manner \\
\hline \multicolumn{2}{|l|}{ Relationship quality } \\
\hline \multirow[t]{5}{*}{$\alpha=0.80$} & Index of satisfaction (strongly agree $7 \ldots$ strongly disagree 1 ) \\
\hline & I think a service provider is favorable \\
\hline & I am pleased with a bank employee \\
\hline & I am satisfied with bank employees \\
\hline & I am satisfied with bank's overall services \\
\hline \multirow[t]{6}{*}{$\alpha=0.76$} & Index of trust (strongly agree $7 \ldots$ strongly disagree 1 ) \\
\hline & A bank employee keeps promises \\
\hline & A bank employee is sincere \\
\hline & A bank employee is reliable \\
\hline & A bank employee is honest \\
\hline & A bank employee puts clients' interests first \\
\hline \multicolumn{2}{|l|}{ Relationship continuity } \\
\hline \multirow[t]{4}{*}{$\alpha=0.78$} & (strongly agree $7 \ldots$ strongly disagree 1 ) \\
\hline & I believe a bank employee will provide better service in the future \\
\hline & I will not switch to another bank \\
\hline & I will always be proud of this bank \\
\hline \multicolumn{2}{|l|}{ Word of mouth } \\
\hline \multirow[t]{3}{*}{$\alpha=0.76$} & (strongly agree $7 \ldots$ strongly disagree 1 ) \\
\hline & I want to recommend this bank to others \\
\hline & I want to tell other persons about good things of this bank \\
\hline
\end{tabular}

Table 2. Item Purification

\section{Constructs}

Antecedents

$\begin{array}{ll} & \text { Relational orientation } \\ & \text { Mutual Disclosure } \\ & \text { Service providers' attributes } \\ \text { Relationship quality } & \text { Satisfaction } \\ & \text { Trust } \\ \text { Consequences } & \text { Relationship continuity } \\ & \text { Word of mouth }\end{array}$

Initial items Final items

$\begin{array}{cc}7 & 6 \\ 8 & 7 \\ 6 & 5 \\ 13 & 11 \\ 5 & 5 \\ 7 & 6 \\ 4 & 4 \\ 2 & 2\end{array}$


Table 3. Correlation Matrix

\begin{tabular}{|c|c|c|c|c|c|c|c|c|c|}
\hline & Men & SD & SO & RO & MD & $\mathbf{S A}$ & RQ & $\mathbf{R C}$ & WM \\
\hline Client orientation & 6.44 & 1.06 & 1 & & & & & & \\
\hline Relational orientation & 6.23 & 1.19 & 0.56 & 1 & & & & & \\
\hline Mutual disclosure & 5.20 & 1.28 & 0.23 & 0.30 & 1 & & & & \\
\hline $\begin{array}{ll}\text { Service } & \text { providers' } \\
\text { attributes } & \end{array}$ & 6.33 & 1.22 & 0.70 & 0.55 & 0.30 & 1 & & & \\
\hline Relationship quality & 6.76 & 1.23 & 0.72 & 0.77 & 0.29 & 0.46 & 1 & & \\
\hline Relationship continuity & 4.61 & 1.16 & 0.31 & 0.42 & 0.22 & 0.25 & 0.51 & 1 & \\
\hline Word of mouth & 5.36 & 1.08 & 0.38 & 0.48 & 0.12 & 0.21 & 0.23 & 0.18 & 1 \\
\hline
\end{tabular}

Table 4. Structural Model Results

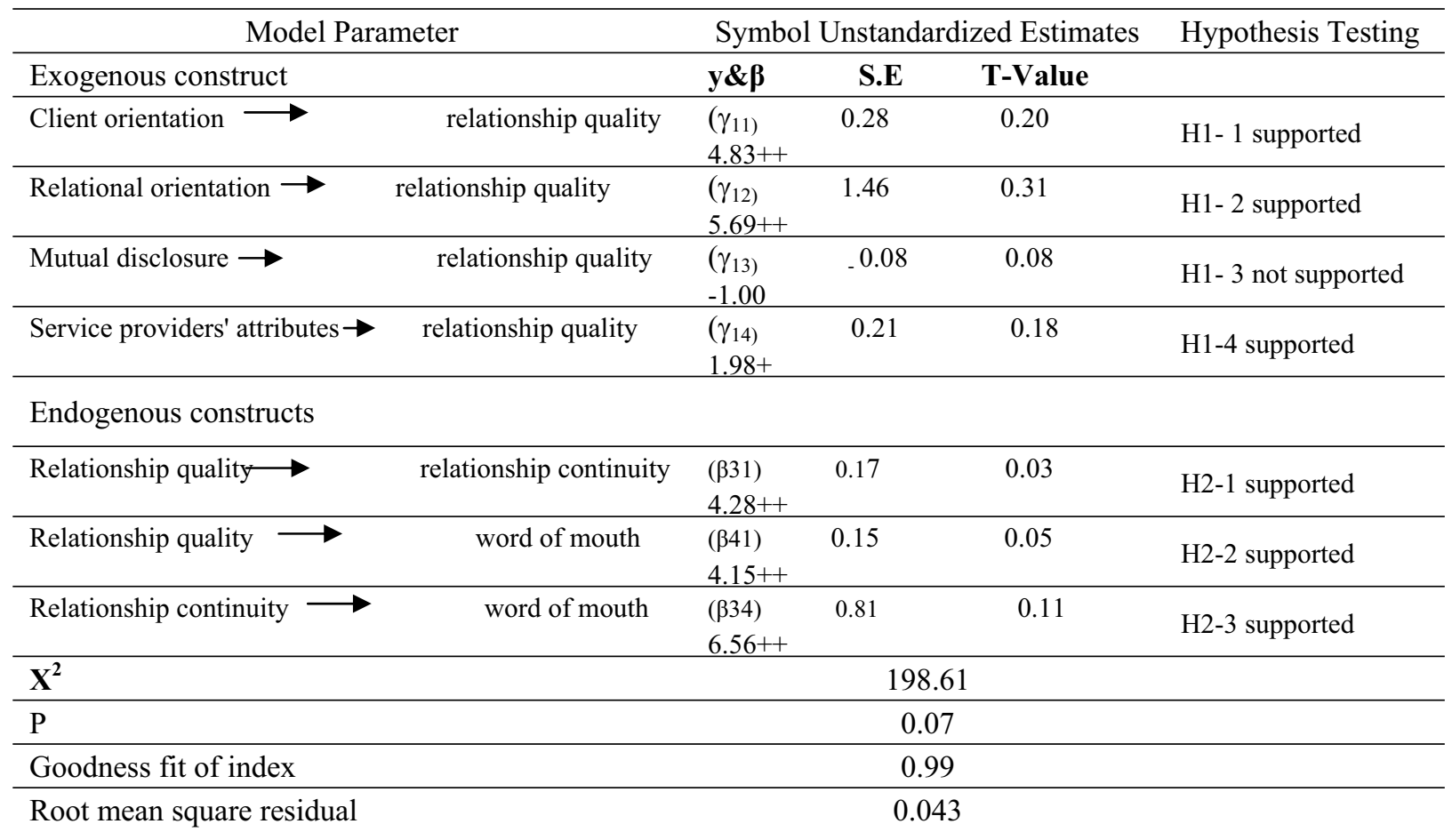

+ Significant at the 0.05 level

++ Significant at the 0.01 level 


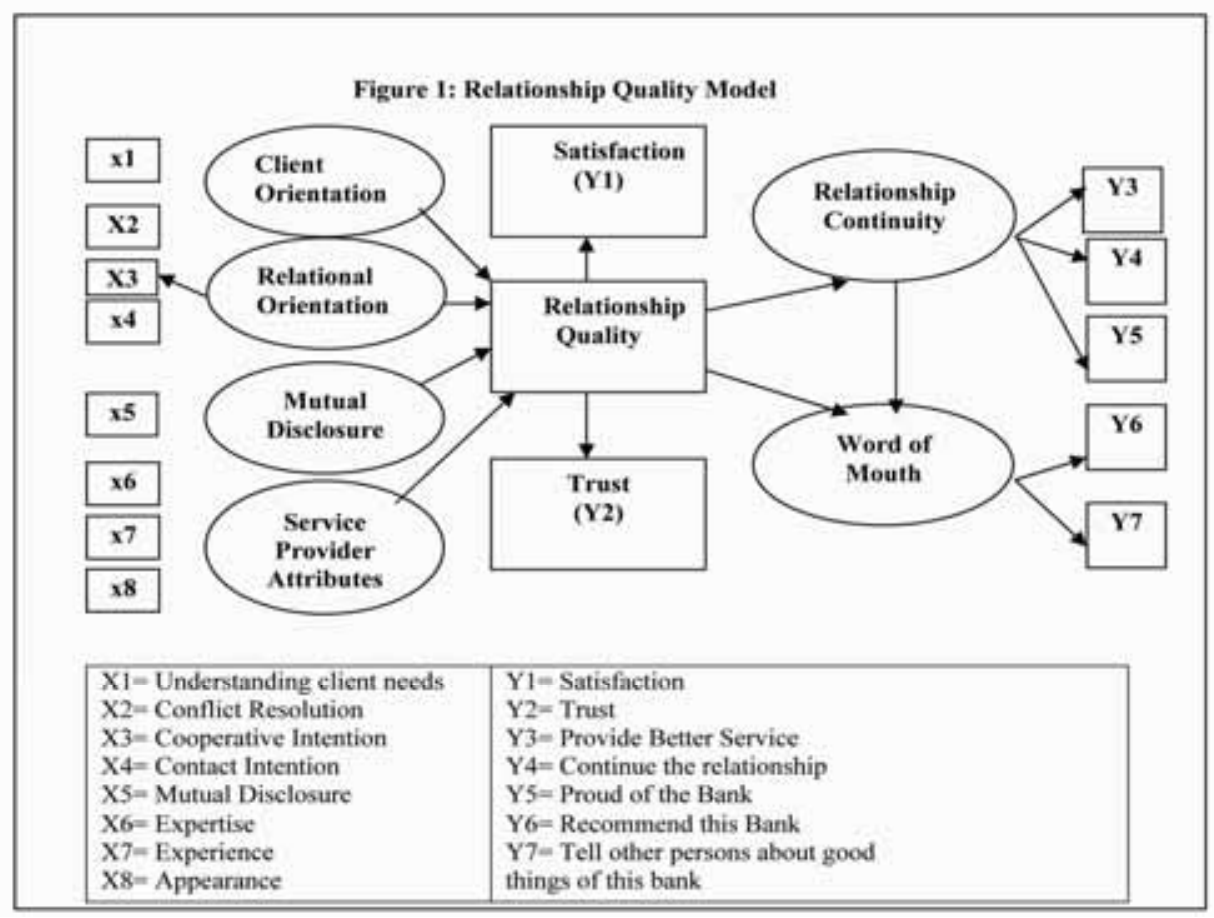

